\title{
Drug-induced Pulmonary Hypertension?
}

\author{
F. FOLLATH，F. BURKART，W. SCHWEIZER
}

\section{Summary}

Of 40 patients with obstructive pulmonary hypertension studied in Basle, Switzerland, during the period 1966-68, 32 had been taking an anorectic drug, aminorex fumarate. Rapidly progressing exertional dyspnoea, central chest pain, and syncope on effort were characteristic features. The absence of the usual causes of pulmonary vascular disease seems to suggest the possibility of drug-induced pulmonary hypertension. Further studies are necessary, however, to clarify the role of aminorex fumarate in this condition.

\section{Introduction}

Obstructive pulmonary hypertension occurs most commonly after recurrent pulmonary thromboembolism (Goodwin et al., 1963). When major embolic episodes or pulmonary infarction cannot be shown the aetiology of the vascular obstruction usually remains unknown and, especially in young women, "primary" pulmonary hypertension is cansidered. Recently a sudden increase in the incidence of rapidly developing pulmonary vascular disease was reported from several European countries (Gurtner et al., 1968, Harmjanz et al., 1968, Schwingshackl et al., 1969). A common finding in these series was the prolonged use of an anorectic drug in most patients, which has therefore been suspected of playing some aetiological part (Schweizer, 1969).

This paper describes studies of a group of 40 patients observed during a three-year period in Basle.

\section{Patients and Methods}

Forty patients ( 37 women and 3 men) with obstructive pulmonary hypertension were studied from January 1966 to December 1968. Their ages ranged from 31 to 72 (average 50) years. All cases were evaluated by physical examination, electrocardiography, chest $x$-ray examination, right heart catheterization, and pulmonary function studies. Lung scan was done in 25 , pulmonary angiography in 8 , and bilateral ascending phlebography in 14 cases. Detailed information was obtained from each patient and the referring physician on previous drug treatment, operations, periods of prolonged bed rest, pregnancies, and venous disorders of the lower extremities.

\section{Results}

Rapidly progressing exertional dyspnoea was the first dominating symptom in all cases. Central chest pain (16 patients) and syncope on effort (nine patients) were other characteristic features. Only seven patients had previously

Medical Department, University Hospital, Basle, Switzerland

F. FOLLATH, M.D., Clinical Assistant

F. BURKART, M.D., Cardiologist

W. SCHWEIZER, M.D., Professor, Head of Cardiology Division

had recognized pulmonary emboli (three postoperatively, two postpartum, one during acute thrombophlebitis, and one of unknown cause). All others had been perfectly well until their present illness. A feature common to most patients was the prolonged intake of the anorectic drug aminorex fumarate (2 - amino - 5 - phenyl - 2 - oxazoline - fumarate), which has been widely used in Switzerland since 1965 to treat obesity (Table I). The treatment (14-42 $\mathrm{mg} /$ day) lasted more than one year in 11, 6-12 months in five, and 3-6 months in seven patients. In most the dyspnoea began during or shortly after the intake of aminorex fumarate. Only one of the patients used oral contraceptives.

A large " $a$ " wave in the jugular venous pulse, abnormal right ventricular impulse, accentuation of the pulmonary closure sound, and atrial sound were the most frequent physical findings (Table II). Electrocardiographic and radiological signs of pulmonary hypertension were nearly always present. Cardiac catheterization (Table III) showed a pronounced rise in pulmonary artery pressure (mean $44.4 \mathrm{~mm} \mathrm{Hg}$ ), a high pulmonary arteriolar resistance (mean 6.4 units) and an abnormal right ventricular end-diastolic pressure (mean $10.3 \mathrm{~mm} \mathrm{Hg}$ ). During exercise a further definite increase of the pulmonary artery pressure (mean $66.9 \mathrm{~mm} \mathrm{Hg}$ ) was noted.

Pulmonary function studies showed decreased arterial $\mathrm{Po}_{2}$ and $\mathrm{PCO}_{2}$ and mild restrictive ventilatory changes as the common pattern. No obstructive bronchitis or other lung disease was found. Detailed results will be published elsewhere. With the exception of two cases with known pulmonary embolism, the large and medium branches of the pulmonary artery appeared patent on lung scan and/or pulmonary angiography.

TABLE I-History of Drug Treatment. Aminorex Fumarate Used in 32 out of 40 Patients

\begin{tabular}{|c|c|c|c|c|c|c|}
\hline \multicolumn{3}{|c|}{$\begin{array}{l}\text { Duration of } \\
\text { Treatment }\end{array}$} & \multicolumn{2}{|c|}{$\begin{array}{c}\text { No. of } \\
\text { Patients }\end{array}$} & Onset of Dyspnoea & $\begin{array}{l}\text { No. of } \\
\text { Patients }\end{array}$ \\
\hline $\begin{array}{l}1 \text { year } \\
6-12 \text { months } \\
\text { 3-6 months } \\
1 \text { month } \\
3 \text { weeks } \\
\text { Unknown }\end{array}$ & $\begin{array}{l}\cdots \\
\because \\
\cdots \\
\cdots \\
\ldots\end{array}$ & $\begin{array}{l}\cdots \\
\cdots \\
\cdots \\
\cdots\end{array}$ & $\begin{array}{l}\because \\
\because \\
\because \\
\because\end{array}$ & $\begin{array}{r}11 \\
5 \\
7 \\
3 \\
1 \\
5\end{array}$ & $\begin{array}{l}\text { During treatment } \\
\text { Within } 3 \text { months after treatme } \\
3-6 \text { months after treatment } \\
>1 \text { year after treatment } \\
\text { Exact time relation unknown }\end{array}$ & $\begin{array}{lr}\therefore & 18 \\
\therefore \text { nt } & 4 \\
\cdots & 2 \\
\therefore & 1 \\
\cdots & 5\end{array}$ \\
\hline
\end{tabular}

TABLE II-Physical Signs

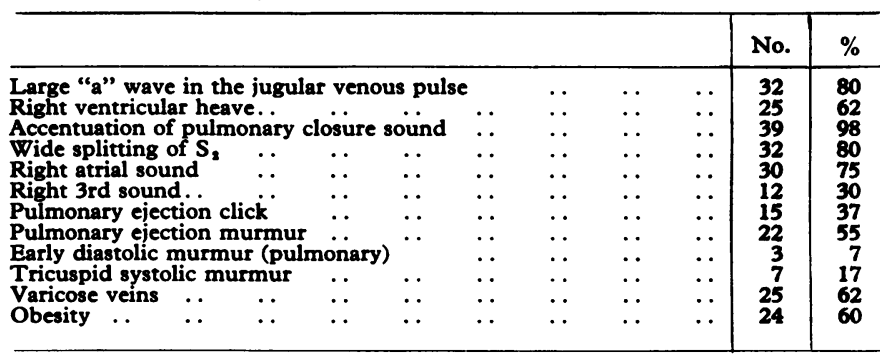

TABLE III-Haemodynamic Data (mean values \pm S.D.)

\begin{tabular}{|c|c|c|c|}
\hline & & Rest & $\begin{array}{c}\text { Exercise } \\
\text { (30 Watts) }\end{array}$ \\
\hline 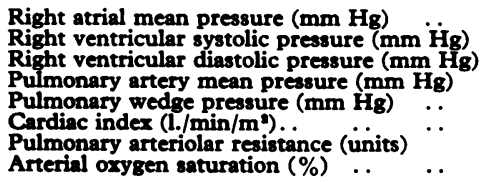 & $\begin{array}{l}\because . \\
\because \\
\therefore \\
\cdots \\
\cdots \\
\cdots\end{array}$ & $\begin{array}{l}7.0 \pm 4 \cdot 3 \\
73.5 \pm 18 \cdot 8 \\
10.3 \pm 4.5 \\
44.4 \pm 10 \cdot 0 \\
6.6 \pm 3.1 \\
3.38 \pm 1.14 \\
6.4 \pm 3.1 \\
94.5 \pm 2.5\end{array}$ & $\begin{aligned} & 14.0 \pm 5.0 \\
& 107.6 \pm 13.5 \\
& 19.0 \pm 7.7 \\
& 66.9 \pm 8.7 \\
& 11.0 \pm \pm .3 \\
& 4.42 \pm 1.25 \\
& 6.8 \pm 3.3 \\
& 91.0 \pm\end{aligned}$ \\
\hline
\end{tabular}


Twenty-five patients had varicose veins (Table IV). Phlebography (14 cases) showed deep-vein occlusion in all nine cases with varicose veins so tested and in two additional cases without clinical evidence of abnormal leg veins. Normal venous circulation was shown in only three instances.

In 18 patients a second haemodynamic study was performed after a mean interval of 10 months. For this group the pulmonary arteriolar resistance was unchanged, while the cardiac output and the right atrial pressure had slightly decreased. The detailed data have been given elsewhere (Burkart et al., 1970).

\section{Discussion}

In 1967 the incidence of obstructive pulmonary hypertension began to increase suddenly in Switzerland. In 1968 a tenfold to twentyfold rise was noted in three of the five cardiac centres of the country (Table V). This seems to be a true increase which could not be explained by improved clinical or haemodynamic methods of investigation or by an increased number of cases referred to cardiovascular units. A similar increase of the disease was noted in Germany and in Austria but not in other European countries.

This dramatic increase of a previously rare disease within a short period of time and a well-defined geographic area points to a common aetiology. Oral contraceptives which may promote the development of pulmonary vascular disease (Oakley and Somerville, 1968) were not considered as only one of our patients had used these drugs. The only common denominator, as in other Swiss series, was the fact that 32 of the 40 patients were treated with aminorex fumarate. A successful or attempted weight reduction by administration of this anorectic drug for several months emerged as a characteristic feature in most patients. The symptoms usually began during or shortly after treatment, and some patients spontaneously reported a further rapid increase of dyspnoea during a second course of aminorex fumarate. It seems highly relevant that the drug had been on sale only in Switzerland, Germany, and Austria, where the increase of the disease had been noted. Furthermore, the drug was introduced in 1966 and heavily sold in 1967-8 until it was withdrawn in November 1968, and the sales curve closely followed the incidence of the disease.

While on the above evidence a relation between aminorex fumarate and the disease appears probable, the pathogenetic mechanism remains unknown. Despite rapidly progressing physical disability neither acute pulmonary embolism nor infarction was ever clinically recognized in most patients. Absence of the "typical" symptoms and signs does certainly

TABLE IV-Venous Disorders of Lower Extremities

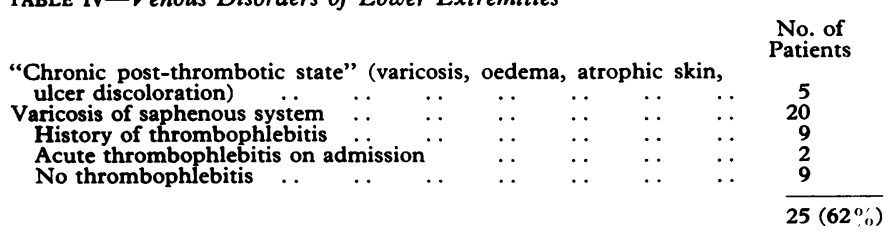

TABLE v-Incidence of Patients with Pulmonary Hypertension of Unknown Origin in Three Swiss Centres (Rivier, 1970)

\begin{tabular}{|c|c|c|c|c|c|c|c|c|c|c|c|c|c|c|}
\hline & & & $\stackrel{2}{ٌ ~}$ & ฆ్ ૂે & ঃ & $\vec{\circ}$ & ชั & مٌ & 。ั & ڤ̊ㅇ & $\stackrel{\circ}{\circ}$ & ڤ & 各 & 。े \\
\hline & $\begin{array}{c}\text { I } \\
\text { III }\end{array}$ & $\begin{array}{l}\cdots \\
\cdots\end{array}$ & $\begin{array}{l}2 \\
0 \\
1\end{array}$ & $\begin{array}{l}2 \\
0 \\
1\end{array}$ & $\begin{array}{l}0 \\
0 \\
1\end{array}$ & $\begin{array}{l}1 \\
1 \\
0\end{array}$ & $\begin{array}{l}0 \\
0 \\
1\end{array}$ & $\begin{array}{l}0 \\
1 \\
0\end{array}$ & $\begin{array}{l}\mathbf{0} \\
1 \\
0\end{array}$ & $\begin{array}{l}1 \\
1 \\
1\end{array}$ & $\begin{array}{l}\mathbf{0} \\
\mathbf{2} \\
\mathbf{2}\end{array}$ & $\begin{array}{r}12 \\
11 \\
9\end{array}$ & $\begin{array}{l}25 \\
28 \\
34\end{array}$ & $\begin{array}{r}10 \\
9 \\
6\end{array}$ \\
\hline \multirow[t]{2}{*}{ Total } & . & . & 3 & 3 & 1 & 2 & 1 & 1 & 1 & 3 & 4 & 32 & 87 & 25 \\
\hline & & & \multicolumn{4}{|c|}{9} & \multicolumn{4}{|c|}{6} & \multicolumn{4}{|c|}{148} \\
\hline
\end{tabular}

not exclude this cause. Recurrent small pulmonary emboli remain silent until severe pulmonary hypertension is established (Owen et al., 1953), and even major emboli are often discovered only at necropsy (Gorham, 1961; Smith et al., 1964). The high proportion of patients with a history of previous thrombophlebitis, signs of chronic venous insufficiency, varicose veins, and phlebographic evidence of deepvein thrombosis in our series would favour repeated emboli. However, in addition to negative clinical findings no occlusion of the pulmonary arteries could be shown by lung scan and/or pulmonary angiography. Emboli were also absent in the few similar cases studied at necropsy (Lang et al., 1969; Jornod et al., 1970). It therefore seems that the pulmonary hypertension is due to some form of small-vessel disease and not to thromboembolism. Thus the high incidence of venous disorders of the lower limbs in our patients could be just a complication of obesity, which has no direct relation to the pulmonary disease.

No specific vasculitis was found on lung biopsy or at necropsy (Gurtner et al., 1968; Lang et al., 1969; Jornod et al., 1970). With one exception-mother and daughter affected, both taking the anorectic drug-no family history was elicited.

Aminorex fumarate has no adverse effect on platelet adhesiveness or coagulation factors (Gurtner et al., 1968). Acute haemodynamic effects of the drug in man have not been reported, but pulmonary and systemic hypertension were found in dogs during infusion of small doses (Kraupp, 1969). Systemic hypertension was not present in our patients, therefore a generalized vasoconstriction is unlikely. An isolated action of aminorex fumarate or some of its metabolites on the pulmonary vascular system would be a theoretical possibility. The experiments of Kay et al., (1967), who produced isolated pulmonary hypertension in rats by feeding Crotalaria spectabilis seed, are relevant here. There is, however, at present no definite indication that a similar reaction could occur by any substance in man. To clarify the exact role of aminorex fumarate in pulmonary vascular disease further studies are necessary. Possibly these studies will give a clue to the better understanding of the mechanism in the hitherto rare primary pulmonary hypertension (Dresdale et al., 1951; Heath et al., 1957; Schweizer et al., 1959; Fowler et al., 1966).

\section{References}

Burkart, F., Follath, F., and Jenzer, H. R. (1970). Schweizerische medizinische Wochenschrift, 100, 146.

Dresdale, D. T., Schultz, M., and Michtom, R. I. (1951). American fournal of Medicine, 11, 686.

Fowler, N. O., Black Schaffer, B., Scott, R. C., and Gueron, M. (1966). American fournal of Medicine, 40, 331

Goodwin, J. F., Harrison, C. V., and Wilcken, D. E. L. (1963). British Medical fournal, 1, 701

Gorham, L. W. (1961). Archives of Internal Medicine, 108, 76. Gurtner, H. P., Gertsch, M., Salzmann, C., Scherrer, M., and Wyss, F. (1968). Schweizerische medizinische Wochenschrift, 98, 1579, 1695.

Harmianz, D. et al. (1968). Deutsche medizinische Wochenschrift, 93, 2351. Heath, D., Whitaker, W., and Brown, J. W. (1957). British Heart fournal, $19,83$.

Jornod, J., Widgren, S., and Fischer, G. (1970). Schweizerische medizinische Wochenschrift, 100, 151.

Kay, J. M., Harris, P., and Heath, D. (1967). Thorax, 22, 176.

Kraupp, O. (1969). Wiener Zeitschrift für innere Medizin und ihre Grenzgebiete, $50,493$.

Lang, E., Haupts, E. J., Koehler, J. A., and Schmidt, J. (1969). Münchener medizinische Wochenschrift, 111, 405.

Oakley, C. M., and Somerville, J. (1968). Lancet, 1, 890.

Owen, W. R., Thomas, W. E., Castleman, B., and Bland, E. F. (1953) New England Fournal of Medicine, 249, 919 .'

Rivier, J. L. (1970). Schweizerische medizinische Wochenschrift, 100, 143, 154.

Schweizer, W. (1969). Praxis, 58, 701.

Schweizer, W., Herzog, H., Jenny, M., and von Capeller, D. (1959).

Cardiologia, 35, 365.
Schwingshackl, H., Amor, H., and Dienstl, F. (1969). Deutsche medizinische Wochenschrift, 94, 639 .

Smith, G. T., Dammin, G. J., and Dexter, L. (1964). Fournal of the American Medical Association, 188, 143. 